\title{
THE EFFECT OF INFLATION, BI RATE AND EXCHANGE ON PROFITABILITY IN SHARIA BANKING IN INDONESIA PERIOD OF 2009-2019
}

\author{
Fuadi $^{1}$, Saparuddin ${ }^{2}$, Sugianto $^{3}$ \\ Fakultas Ekonomi dan Bisnis Universitas Malikussaleh \\ 2,3 \\ Fakultas Ekonomi dan Bisnis Islam Universitas Islam Negeri Sumatera Utara
}

E-mail: ${ }^{1)}$ fuadi.msm@ unimal.ac.id,,${ }^{2)}$ saparuddin.siregar@uinsu.ac.id,${ }^{3)}$ sugianto@uinsu.ac.id

\begin{abstract}
This study examined the effect of inflation, BI Rate, and exchange rate on profitability in Islamic banking in Indonesia during 2009-2019. The population and sample in this study were all Islamic banking in Indonesia obtained by purposive sampling technique. This study used quantitative secondary data sourced from financial statements accessed on the official website of Bank Indonesia and the Financial Services Authority. The data analysis method used was Vector AutoRegressive (VAR) analysis with the help of Eviews 10. The results of the Variance Decomposition (VD) test showed that inflation could affect Return on Assets (ROA) of 0.62\%. It indicated that inflation had a low or insignificant effect on the Return On Assets (ROA) of Islamic banking. BI Rate could affect the Return on Assets (ROA) of 0.13\%, which indicated that inflation had a low or insignificant effect on the Return On Assets (ROA) of Islamic banking, while the exchange rate could affect the Return on Assets (ROA) of 1.89\%, which indicated that the exchange rate had a significant effect on the Return On Assets (ROA) of Islamic banking. Based on the results of this study, it concluded that the exchange rate was more dominant in influencing the Return on Assets (ROA) of Islamic banking in the short and long term.
\end{abstract}

Keywords: Inflation, BI Rate, Exchange Rate, and Return On Assets (ROA)

\section{INTRODUCTION}

In today's modern world, the role of banking in advancing the economy of a country is very large. Until now, the life of the world economy cannot be separated from the banking world. Bank is one of the financial institutions that have an important role in the economy of a country as a financial intermediary institution. Banks in Article 1 paragraph (2) of Law no. 10 of 1998 concerning amendments to Law no. 7 of 1992. In Indonesia the banking system used is a dual banking system in which two types of bank operations operate, namely Islamic banks and conventional banks. 2 Therefore, the policies adopted by the government through Bank Indonesia are certainly different for the two types of banks. Islamic banks do not recognize the interest system, so that the profit can be sourced from profit sharing with business actors who use funds from Islamic banks as well as investments from Islamic banks themselves. (Khaerunnisa, 2019). The development of Islamic banking in Indonesia has become a benchmark for the success of the existence of the Islamic economy. Bank Muamalat as the first Islamic bank and a pioneer for other Islamic banks has already implemented this system in the midst of the proliferation of conventional banks.

Islamic banking is basically a banking system whose business is based on Islamic sharia principles with reference to the Qur'an and Al-Hadith. The purpose of a system that is in accordance with Islamic sharia is to operate in accordance with the provisions of Islamic sharia, especially regarding the procedures for converting, for example by avoiding practices that contain elements of usury. Researchers chose the Islamic banking industry because this industry is very necessary for the smooth running of the real sector economic activities. Especially in Islamic 
banking because it is based on the consideration that the number of banks currently seems to be growing in Indonesia

Inflation has a bad impact on the economy, it causes a decline in public interest in investing their money in savings, investing and the desire to produce decreases. Inflation causes prices to rise, it is very detrimental to the community because it is difficult to reach the prices of daily necessities that continue to increase, besides that inflation is very detrimental to companies because it causes increased production costs and operational costs, resulting in a decrease in bank profits. (Marwansyah, 2019).

The magnitude of the interest rate (BI Rate) is one of the factors of bank profitability to determine the amount of interest rates offered to the public. The increase in the BI rate does not directly affect Islamic banks. This is because in the implementation of its business Islamic banks do not refer to 9 interest rates. In addition, Islamic banks have also implemented several internal policies, including increasing the profit-sharing ratio offered to anticipate an increase in the BI rate (Syah, 2018).

In banking, apart from the BI rate, we need to look at the foreign exchange rate which has an influence on the level of profitability. The foreign exchange rate will determine the real investment returns. A declining currency will obviously reduce the purchasing power of the income and capital gains of any type of investment. This decrease in investment will affect the operational activities of Islamic banks. The existence of the influence of currency exchange rates on bank profitability identifies if the exchange rate appreciates or depreciates, it will have an impact on bank profitability. The strengthening of the rupiah exchange rate against the dollar will increase the profitability of Islamic banking. From the phenomenon above, it is interested to conduct research on the issue of inflation.

\section{LITERATURE REVIEW}

\subsection{Syariah banking}

According to (Antonio, 2001) Islamic banks are banks that operate without relying on interest. Islamic banks or commonly called interest-free banks are financial or banking institutions whose operations and products are developed based on the Qur'an and the Hadith of the Prophet SAW. According to (Karim, 2004) Islamic banks are financial institutions whose main business is providing credit, and other services in payment traffic and circulation that operate in accordance with sharia principles.

\subsection{Profitability}

Profitability as the ability of a company to earn a profit with total assets, sales, and long-term debt within a certain period. The profitability ratio measures the ability of 18 companies to generate profits by using the company's resources, such as assets, capital, or company sales. (Hidayati, 2014) According to (Kasmir, 2008) in (Rivai, 2017) defines profitability as a ratio to assess the company's ability to seek profit. Profitability itself can be measured using various ratios. One of them is by using the ratio of return on assets (Return On Assets). Return on Assets (ROA) is an overall measurement of profitability.

\subsection{Inflation}

In an unstable economy, inflation can occur at any time. Inflation is a condition of constantly increasing prices in general and high inflation will lead to high production costs. In simple terms, inflation is defined as an increase in prices in general and continuously. An increase in the price of one or two goods alone cannot be called inflation unless the increase is widespread or results in an increase in the price of other goods. (Welta, 2017) Inflation is the process of increasing general prices of goods continuously (Nopirin, 2007:25). An increase in the price of just one or two kinds of goods cannot be called inflation unless the increase has an impact on increasing the prices of most other goods. Meanwhile, according to Sukirno (2006:14), Inflation is a process of increasing 
prices in an economy. So, from the conclusion above, inflation is the tendency of prices to rise in general and continuously. (Swandayani, 2012).

\subsection{Definition of BI Rate}

The BI Rate is the policy interest rate that reflects the monetary policy stance or stance set by Bank Indonesia and announced to the public. The BI Rate is announced by the Board of Governors of Bank Indonesia at every monthly meeting of the board of governors and implemented in monetary operations carried out by Bank Indonesia through liquidity management in the money market to achieve monetary policy operational targets. (Shah, 2018). Changes in the BI interest rate (BI rate) were followed by changes in deposit interest rates and credit interest rates with movements in a positive direction (Sahara, 2013). The interest rate is the price charged by an economic unit that has a surplus to an economic unit that takes a deficit on loans it provides from its savings. (Mufidhoh, 2017).

According to (Karim, 2008) in (February, 2017) the interest rate of Bank Indonesia can affect the profitability of Islamic banks. When interest rates rise, it will be followed by an increase in deposit interest rates which has a direct impact on a decrease in third party funding sources for Islamic banks.

\subsection{Exchange Rate (Exchange Rate)}

Exchange rate is the number of units or units of a certain currency needed to obtain or buy one unit or units of another type of currency. If the demand for a currency increases, while the supply remains constant or decreases, the exchange rate of that currency will rise. Conversely, if the supply of a currency increases, while the demand remains or decreases, the value of that currency will weaken (Adiyadnya, 2013).

According to (Sukirno, 2006b) the exchange rate or exchange rate is a comparison of the value of a country's currency with the currency of another country. According to Hasibuan (2005:14), the foreign exchange rate is a comparison of the exchange rate of a country's currency with foreign currencies or a comparison of exchange rates between countries.

\section{IMPLEMENTATION METHOD}

The objects in this research are inflation, BI rate, exchange rate and profitability in Islamic banking which have been audited by Bank Indonesia (BI) and during the 2009-2019 period. The location of this research is in Indonesian Islamic Banking which has presented the publication of financial reports published by the Financial Services Authority (OJK).

\subsection{Population}

All Indonesian Islamic Banking with a span of 10 years of observation, which is between 2009-2019.

\subsection{Sample}

According to (Sugiyono, 2015) the sample is part of the number and characteristics possessed by the population. The sampling technique in this study was using purposive sampling with the aim of obtaining samples that matched the research objectives. So it can be interpreted that purposive sampling is sampling deliberately in accordance with the required sample criteria. The criteria used to determine the research sample are: Islamic banking that has published complete financial reports, both completeness of data, clarity of data, availability of data collected in a row for the period 2009-2019.

\section{RESULTS AND DISCUSSION}


The result of this research is that there is an effect of Inflation, BI Rate and Exchange Rate on Profitability (ROA). Based on the results of the Variance Decomposition test with the EViews 10 program, it shows that all independent variables, namely Inflation, BI Rate and Exchange Rate, have variances in influencing the Return on Assets (ROA) variable, thus it can be concluded that the hypothesis in this study is accepted. From the table of the results of the Variance Decomposition of ROA test at the beginning of the observation, it can be seen that the exchange rate variance is more dominant in influencing Return on Assets (ROA) than the others, which is $0.50 \%$ which is then followed by $0.27 \%$ Inflation and 0.01 BI Rate. \% until the end of the observation, the fixed exchange rate which more dominantly affects the Return on Assets (ROA) is $1.89 \%$, followed by the inflation variable at $0.62 \%$, and the BI Rate at $0.13 \%$.

However the exchange rate has a variance which tends to increase towards the Return on Assets (ROA). It shows that the exchange rate more dominantly affects the Return on Assets (ROA) in the long term than other variables, namely inflation and the BI Rate.

\subsection{Inflation ability affects Profitability (ROA)}

Based on the tests conducted with the variance decomposition test tool, it proves that inflation has the ability to affect the Return on Assets (ROA) from the beginning to the end of the observation. Inflation variance tends to increase until the end of the observation starting from $0.27 \%$ which then increases to $0.62 \%$. However, the results of the causality test prove that there is no causal relationship whatsoever for the two variables of inflation and ROA. Meanwhile, from the results of the Impulse Response Function test, it can be seen that the ROA responded positively to inflation shocks and was very balanced until the 10th period. Meanwhile, inflation responded positively to ROA shocks and appeared to be quite balanced.

\subsection{The ability of the BI Rate to affect Profitability (ROA)}

Based on the tests conducted with the variance decomposition test tool, it proves that the BI Rate has the ability to influence from the beginning to the end of the observation. The BI Rate variance tends to increase until the end of the observation starting from $0.01 \%$ which then increases to $0.13 \%$. However, the results of the causality test prove that there is no causal relationship between the two BI Rate and ROA variables. While from Impulse Response Function test results show that ROA responds negatively with there was a shock from the BI Rate, but the movement remained stable until the 10th period. Meanwhile, the BI Rate seemed to respond positively to ROA shocks and the movement was quite stable.

\subsection{The Ability of the Exchange to Affect Profitability (ROA)}

Based on the tests carried out with the variance decomposition test tool, it proves that the exchange rate has the ability to affect the Return on Assets (ROA) from the beginning to the end of the observation. The exchange rate variance tends to increase until the end of the observation starting from $0.50 \%$ which then increases to $1.89 \%$. This proves that the role of the exchange rate in influencing Return on Assets (ROA) is quite dominant in the long run. However, the results of the causality test prove that there is simply no causality whatsoever for the two variables Exchange Rate and ROA. Meanwhile, from the test results Impulse Response Function seen that the ROA is very balanced in response to exchange rate shocks. Meanwhile, the exchange rate seemed to respond negatively to ROA shocks, but the movement became more balanced until the 10 th period.

\section{CONCLUSION}

Based on the results of the data analysis presented in the previous chapter, it can be concluded that the results of the analysis using the VAR method, namely the variance decomposition test at alpha 5\% with the help of Eviews 10, show that the variables of inflation, BI Rate and Exchange Rate have variances in influencing Return on Assets ( ROA), this can be seen 
from the results of observations in the first to the last period. At the beginning of the observation, inflation has an effect of $0.27 \%$, the BI Rate has a less dominant influence from the beginning of the observation to the end of the observation period, which is $0.01 \%$.

Meanwhile, the exchange rate has the most dominant influence compared to other variables, which is $0.50 \%$ of its performance or the variance continues to increase until the end of the observation period. As for the meaning of the results of this study, it can be concluded that the exchange rate is more dominant in influencing Return on Assets (ROA) in the short and long term. To answer the problems that have been stated at the beginning, the authors make the results of the study with the following details:

1. Inflation has the ability to affect the Return on Assets (ROA) of $0.62 \%$. This shows that although inflation has increased, the profit earned by Islamic banks does not experience a significant decline and vice versa if inflation decreases Profits obtained by Islamic Banks did not increase significantly. This means that inflation has a low or insignificant effect on the Return On Assets (ROA) of Islamic banking.

2. BI Rate has the ability to influence the Return on Assets (ROA) of $0.13 \%$. This indicates that the increase in the BI rate does not directly affect Islamic banks because in carrying out their business, Islamic banks do not refer to interest rates. In addition, Islamic banks have also implemented several internal policies, including by increasing the profit sharing ratio offered to anticipate the increase in the BI Rate. This means that the BI Rate has a low or insignificant effect on the Return on Assets (ROA) of Islamic banking.

3. The exchange rate has the ability to influence the Return on Assets (ROA) of $1.89 \%$. This illustrates that if the currency experiences appreciation or depreciation, it will have an impact on the profitability of Islamic banks. This shows that the exchange rate has a significant effect on the return on assets (ROA) of Islamic banking. From the results of the research above, it can be seen that the Return on Assets (ROA) in its development is more influenced by the exchange rate, which is $1.89 \%$ compared to inflation and the BI rate. This is expected for the banking sector to maintain the stability of the exchange rate so that profits can increase.

\section{REFERENCES}

Adiyadnya, I. N. S. dkk. (2013). Pengaruh Beberapa Variabel Ekonomi Makro Terhadap Profitabilitas dan Return Saham Pada Industri Perbankan di BEI. EJurnal Ekonomi Dan Bisnis Universitas Udayana, 3, 2579-2608.

Alim, S. (2013). Analisis Pengaruh Inflasi dan BI Rate Terhadap Return on Asset (ROA) Bank Syariah di Indonesia. Jurnal Modernisasi, 10(3), 201-220.

Antonio, M. S. (2001). Bank Syariah dari Teori ke Praktek. Yogyakarta: Gema Insani.

Dahlan, A. (2012). Bank Syariah: Teoritik, Praktik, Kritik. Yogyakarta: TERAS.

Darmadi, H. (2013). Metode Penelitian Pendidikan dan Sosial. Bandung: Alvabeta.

Dendawijaya, L. (2009). Manajemen Perbankan. Jakarta: Ghalia Indonesia.

Dewi, O. R. (2018). Pengaruh Dana Pihak Ketiga, Inflasi, BI Rate dan Kurs terhadap Profitabilitas Perbankan Syariah di Indonesia Periode 2013-2017.

Skripsi Fakultas Ekonomi dan bisnis Islam Universitas Islam Negeri Raden Intan Lampung.

Dwijayanthy, F. (2009). Analisis Pengaruh Inflasi , BI Rate, dan Nilai Tukar Mata Uang terhadap Profitabilitas Bank. 3(2), 87-98.

Enders, W. (2004). Aplied Economic Time Series. New York: ohn Willey \& Sons Inc.

Fatma, L. (2019). Pengaruh Inflasi dan Nilai Tukar Mata Uang Asing Terhadap Profitabilitas Perbankan Syariah di Indonesia. In Skripsi Universitas Islam Negeri Sumatra Utara Medan.

Geovani, I., Nurkhotijah, S., Kurniawan, H., Milanie, F., \& Ilham, R. N. (2021). JURIDICAL ANALYSIS OF VICTIMS OF THE ECONOMIC EXPLOITATION OF CHILDREN UNDER THE AGE TO REALIZE LEGAL PROTECTION FROM HUMAN RIGHTS ASPECTS: RESEARCH STUDY AT THE OFFICE OF SOCIAL AND COMMUNITY 
EMPOWERMENT IN BATAM CITY. International Journal of Educational Review, Law And Social Sciences (IJERLAS), 1(1), 45-52.

Hasibuan, M. (2006). Manajemen Perbankan. Jakarta: Bumi Aksara.

Hidayati, A. N. (2014). Pengaruh Inflasi, BI rate dan Kurs Terhadap Profitabilitas Bank Syariah. AN-NISBAH, 01(46).

Ilham, R. N., Sinaga, S., Putri, D. E., Sinta, I., \& Fuadi, F. (2021). EFEK DARI LEVERAGE DAN UKURAN PERUSAHAAN DALAM MEMENGARUHI TINGKAT PROFITABILITAS. JURNAL ILMIAH EDUNOMIKA, 5(02).

Ikshsan, I. (2014). Analisis Vector Auto Regresion (VAR) untuk Melihat Hubungan Kausalitas Antara Variabel- Variabel Ekonomi di Sulawesi Selatan. Skripsi Universitas Islam Negeri Alaudidin Makassar.

Juliansyah, Y. M. dan H. (2019). Pengaruh Inflasi , Pengeluaran Pemerintah dan Ekspor Terhadap Pertumbuhan Ekonomi di Indonesia. Jurbal Ekonomi Regional Unimal, 02(April), 37-50.88

Karim, A. (2004). Bank Islam: Analisis Fiqh dan Keuangan. Jakarta: PT. Raja Grafindo Persada.

Karim, A. (2006). Bank Islam: Analisis Fiqh dan Keuangan. Jakarta: PT. Raja Grafindo Persada.

Karim, A. (2008). Ekonomi Makro Islami. Jakarta: PT Raja Grafindo Persada.

Kasmir. (2008). Bank dan Lembaga Keuangan Lainnya. Jakarta: Raja Grafindo Persada.

Khaerunnisa, A. (2019). Analisis Pengaruh Kondisi Makro Ekonomi Terhadap Perubahan Laba Operasional Pada Bank Umum Syariah Tahun 2016-2018. In Skripsi Universitas Islam Negeri Walisongo Semarang.

Lailiyah, N. H. (2017). Analisis Pengaruh Inflasi, BI Rate dan Nilai Tukar Mata Uang Asing Terhadap Profitabilitas Pada Bank BRISyariah Periode 2011-2015. In Skripsi Institut Agama Islam Negeri Surakarta.

Madura, J. (2009). International corporate Finance, Keuangan Perusahaan International (Edisi Ke 8). Jakarta: Salemba Empat.

Marimin, A. dkk. (2015). Perkembangan Bank Syariah di Indonesia. Jurnal Ilmiah Ekonomi Islam, 01, 75-87.

Marwansyah, S. R. dan S. (2019). Pengaruh Inflasi, BI Rate, CAR, NPL, BOPO Terhadap Profitabilitas Pada Bank Bumn. Jurnal Mantik Penusa, 3(1), 117-122.

Mishkin, F. S. (2008). Ekonomi Uang, Perbankan dan Pasar Keuangan (Buku 1. Ed). Jakarta: Salemba Empat.

Mufidhoh, U. dkk. (2017). Analisis Pengaruh Inflasi, Suku Bunga dan Nilai Tukar Terhadap Kinerja Bank Syariah BUMN (Periode 2014-2017). 1, 71-90.

Muhammad. (2005). Manajemen Bank Syariah. Yogyakarta : UPP AMPY YKPN.

Muliati, F. A. dan L. (2019). Analisis Pengaruh Inflasi Terhadap Profitabilitas Bank Umum Syariah Devisa di Indonesia. 2017.

Nasir, M. dkk. (2016). Analisis Variabel Makroekonomi terhadap Indeks Saham Syariah Indonesia dengan Metode Pendekatan Vector Autoregression. JURNAL EKONOMI DAN BISNIS, 15(1), 53-63.

Nopirin. (2009). Ekonomi Moneter (Edisi Satu). Jakarta: Penerbit BPFE.

OJK. (2021). Sejarah Perbankan Syariah.89

Pebruary, S. dan S. A. W. I. (2017). Analisa Faktor Makro Ekonomi Terhadap Return On Asset Perbankan Syariah (Studi Kasus Bank Mandiri Syariah). JJI, 2, 73-88.

Pohan, A. (2008). Potret Kebijakan Moneter Indonesia. Yogyakarta: PT. RAJAGRAFINDO PERSADA.

Revalma, A. P. (2019). Pengaruh Inflasi, Kurs dan BI Rate Terhadap Profitabilitas (Studi Kasus Pada Bank Umum Syariah di Indonesia Tahun 2014 - 2018). In Skripsi Institut Agama Islam Negeri Purwokerto.

Rivai, A. (2017). Risiko Pembiayaan Murabahah dan Musyarakah Pada Profitabilitas

Bank Umum Syariah. Jurnal Ekonomi Syariah Dan Filantropi Islam, 1(2), 189- 197. https://doi.org/10.22236/alurban 
Rosanti, N. (2019). Analisis Pengaruh Kurs Rupiah, Inflasi dan BI Rate Terhadap Profitabilitas Bank Umum Syariah di Indonesia Tahun 2015-2018. In Skripsi Institut Agama Islam Negeri (IAIN) Salatiga.

Sahara, A. Y. (2013). Analisis Pengaruh Inflasi, Suku Bunga BI dan Produk

Domestik Bruto Terhadap Return on Asset (ROA) Bank Syariah di Indonesia. Jurnal Ilmu Manajemen, 1, 149-157.

Sucahyo, I. B. (2008). Analisis hubungan suku bunga SBI, pertumbuhan ekonomi, dan financial depening di indonesia. Skripsi. Fakultas Ekonomi Universitas Airlangga. Surabaya., 69.

Sugiyono. (2013). Metode Penelitian Bisnis (Pendekatan Kuantitatif, Kualitatif dan R\&D), Cet. Ke-11. Bandung: Alvabeta.

Sugiyono. (2015). Metode Penelitian Pendidikan (Pendekatan Kuantitatif, Kualitatif dan R dan D). Bandung: CV Alvabeta.

Suhel. (2008). Analisis Model Vector Auto Regression (Var) Terhadap Hubungan

Antara Pertumbuhan Ekonomi Dengan Penanaman Modal Asing (Pma) Di Indonesia. Jurnal Ekonomi Pembangunan, 6, No. 2, 96-113.

Sukirno, S. (2006a). Ekonomi Pembangunan: Proses, Masalah dan Dasar Kebijakan

(Edisi Kedu). Jakarta: Penerbit Prenada Media Group.

Sukirno, S. (2006b). Teori Pengantar Ekonomi Makro. Jakarta: PT. Raja Grafindo Persada.

Sunariyah. (2004). Pengantar Pasar Modal. Jakarta: UUP AMP LPFE UI.

Swandayani, D. M. dan R. K. (2012). Pengaruh Inflasi, Suku Bunga, Nilai Tukar Valas Dan Jumlah Uang Beredar Terhadap Profitabilitas Pada Perbankan90

Syariah Di Indonesia Periode 2005-2009. AKRUAL: Jurnal Akuntansi, 3(2), 147-166.

https://journal.unesa.ac.id/index.php/aj/article/view/279/149

Syah, A. T. (2018). Pengaruh Inflasi, BI Rate, NPF, dan BOPO Terhadap

Profitabilitas Bank Umum Syariah di Indonesia. Jurnal Ekonomi Islam, 6(1), 133-153.

Syaichu, E. S. W. dan M. (2013). Analisis Pengaruh Suku Bunga, Inflasi, CAR, BOPO, NPF Terhadap Profitabilitas Bank Syariah. Journal of Management, 2(2), 1-10.

Welta, F. dan L. (2017). Pengaruh CAR, Inflasi, Nilai Tukar Terhadap Profitabilitas Pada Bank Umum Syariah. 1(1), 85-100.

www.bi.go.id

www.bps.go.id

www.ojk.go.id 
